\title{
TERAPI SEL PUNCA NEURAL PADA PENYANDANG STROKE
}

\author{
${ }^{1}$ Venki F. Tangkuman \\ ${ }^{2}$ Denny J. Ngantung \\ ${ }^{2}$ Arthur Mawuntu
}

\author{
${ }^{1}$ Kandidat Skripsi Fakultas Kedokteran Universitas Sam Ratulangi Manado \\ ${ }^{2}$ Bagian Neurologi Fakultas Kedokteran Universitas Sam Ratulangi Manado \\ Email: venki.f_tangkuman@yahoo.com
}

\begin{abstract}
Stroke is the second order of deaths for the age group above 60 years and the fifth order for the age group 15-59 years. Although there are many kinds of therapies applied to stroke, none are satisfactory cures. An alternative therapy which is very promising, the neural stem cell therapy, is expected to be able to ameliorate stroke patients better, and therefore, can decrease the morbidity and mortality of stroke cases. There are several kinds of stem cells used in research, inter alia embryonal and adult stem cells. The purpose of this stem cell therapy in neurological disorders is to replace the damaged neural cells or to improve their biological function for enhancing brain function. New neuron cells can be produced from stem cell transplantation. Moreover, the mature brain has the ability, although very limited, to produce new neuron cells as a response to brain damage due to stroke.
\end{abstract}

Keywords: neural stem cells, stroke, transplantation

\begin{abstract}
Abstrak: Stroke merupakan penyebab kematian urutan kedua pada kelompok usia di atas 60 tahun dan urutan kelima pada kelompok usia 15-59 tahun. Sampai sekarang ini stroke belum dapat disembuhkan dengan baik walaupun telah banyak jenis pengobatan yang digunakan. Salah satu pengobatan alternatif yang mungkin kelak akan mampu memulihkan pasien stroke secara memuaskan serta menurunkan angka morbiditas dan mortalitas kasus stroke di seluruh dunia khususnya Indonesia yaitu terapi sel punca neuronal. Transplantasi sel punca pada gangguan neurologik termasuk stroke yaitu untuk menggantikan atau memperbaiki fungsi biologik dari sel neuron yang rusak agar dapat mempertahankan atau memulihkan fungsi otak. Sel neuron baru dapat dihasilkan dari transplantasi sel punca. Selain itu, otak dewasa akan terpicu untuk membuat sel neuron baru sebagai respon terhadap kerusakan sehingga akan meningkatkan kualitas penyembuhan pasien stroke.
\end{abstract}

Kata kunci: sel punca neuronal, stroke, transplantasi

WHO memperkirakan sekitar 15 juta orang terkena stroke setiap tahunnya. Stroke merupakan penyebab kematian utama urutan kedua pada kelompok usia di atas 60 tahun dan urutan kelima pada kelompok usia 15-59 tahun. ${ }^{1}$ Di Indonesia, stroke merupakan penyakit nomor tiga yang mematikan setelah jantung dan kanker. Menurut survei tahun 2004, stroke merupakan pembunuh nomor satu di rumah sakit pemerintah di seluruh penjuru Indonesia dengan perkiraan 500.000 penduduk yang terkena stroke. Dari jumlah tersebut, sepertiganya bisa pulih kembali, sepertiga lainnya mengalami gangguan fungsional ringan sampai sedang, dan sepertiga sisanya mengalami gangguan fungsional berat yang mengharuskan penyandang stroke terbaring di tempat tidur. Menurut Yayasan Strok Indonesia (Yastroki) dalam dasa 
warsa terakhir ini terdapat kecenderungan peningkatan jumlah penyandang stroke pada generasi muda yang masih produktif di Indonesia. Hal ini akan berdampak terhadap menurunnya tingkat produktivitas serta dapat mengakibatkan terganggunya kondisi sosial ekonomi keluarga. ${ }^{2}$

Sampai sekarang ini stroke belum dapat disembuhkan dengan memuaskan walaupun dengan menggunakan berbagai macam pengobatan. Sel-sel neuron yang rusak tidak dapat mengalami pemulihan dengan sendirinya. Steinberg dan rekanrekannya dari Universitas Stanford (2008) melakukan penelitian dengan menggunakan sel punca embrional untuk memulihkan tikus yang terkena stroke. ${ }^{3}$ Dengan pemberian terapi sel punca neural, sel-sel neuron yang rusak pada tikus yang terkena stroke dapat tergantikan dengan sel neuron baru oleh karena sel punca merupakan sel yang belum dewasa dan mampu berdiferensisasi menjadi berbagai jenis sel sesuai dengan letak sel tersebut di dalam tubuh. Kultur sel punca dapat menghasilkan selsel neuron baru yang kemudian dapat menumbuhkan aksonnya menuju lokasi yang tepat di otak. ${ }^{4}$ Pengobatan alternatif dengan sel punca neural diharapkan dapat memulihkan penyandang stroke secara memuaskan. ${ }^{3}$

\section{SEL PUNCA}

Sel punca adalah sel yang belum berdiferensiasi, namun dapat berproliferasi memperbanyak diri (self renewal), dan berdiferensiasi menjadi lebih dari satu jenis sel (pluripoten atau multipoten). ${ }^{5,7,9}$ Dengan potensi demikian, sel punca dipandang lebih bernilai untuk digunakan dalam transplantasi sel dibandingkan sel jenis lain dalam tubuh manusia. ${ }^{7}$ Sel punca yang saat ini sering digunakan untuk penelitian biomedik ialah sel punca yang berasal dari embrio, yaitu sel punca embrional. ${ }^{5}$

\section{Sel punca embrional}

Kehidupan setiap manusia di mulai dari proses fertilisasi antara spermatozoa dan oosit di ampula tuba Falopi, yang selanjutnya menghasilkan sebuah sel yaitu zigot. Pada zigot, materi genetik yang tersimpan di dalamnya merupakan kesatuan dari spermatozoa dan oosit. Sel zigot segera aktif membelah dan menghasilkan sel-sel blastomer dalam jumlah yang berlipat ganda $(2,4$, dan seterusnya). Dengan demikian, pada hari ke-3 sampai ke-4 pasca fertilisasi, blastomer yang terbentuk telah berjumlah delapan sel. ${ }^{7}$ Setelah mencapai tahapan ini, embrio akan mulai mengalami kompaksi dan disebut morula, yang ditandai oleh adanya ikatan antar blastomer yang cukup kuat. Seiring dengan terjadinya hal itu, sel-sel di dalam embrio akan terus membelah hingga berjumlah 32 sel. Pada tahap selanjutnya, natrium dipompakan dari dalam ke luar sel, yang menyebabkan keseimbangan di dalam zona pelusida berubah sehingga air dapat masuk ke dalamnya. Peristiwa ini terus berlangsung sampai terbentuknya rongga blastokel. ${ }^{7,18}$ Setelah rangkaian proses ini terjadi, embrio dikatakan telah mencapai tahap blastosis. Sel-sel dalam tahapan ini telah kehilangan sifat totipotensi/pluripoten, karena telah terjadi diferensiasi yang pertama kali, yaitu perubahan blastomer menjadi inner cell mass (massa sel dalam) dan sel trofoblas. Inner cell mass merupakan sel-sel punca embrional yang nantinya akan berdiferensiasi membentuk seluruh jenis sel tubuh, sedangkan sel trofoblas bertanggung jawab pada proses pembentukan plasenta. ${ }^{7}$

\section{Sel punca dewasa}

Sel punca dewasa ialah sel-sel punca yang terdapat di semua organ tubuh terutama sum-sum tulang, dan berfungsi melakukan regenerasi untuk mengatasi dan memperbaiki berbagai kerusakan jaringan yang dapat berakibat nekrosis sel. Sel punca dewasa dapat diambil dari fetus (fetal stem cells), sum-sum tulang (bonemarrow stem cells), dan darah perifer atau tali pusat (umbilical cord blood stem cells). ${ }^{8}$ Sel punca dewasa memiliki setidaknya dua sifat khusus. Pertama, selsel ini mampu membuat salinan sel yang 
identik dengan dirinya sendiri untuk periode waktu yang lama. Kedua, sel punca dewasa mampu berdiferensiasi menjadi jenis sel dewasa dengan karakteristik morfologik dan fungsi tertentu. Asal yang pasti dari sel punca dewasa belum jelas diketahui; oleh karena itu beberapa peneliti mengajukan hipotesis bahwa sel punca yang dicegah untuk berdiferensiasi ini disebarkan dengan mekanisme tertentu yang belum diketahui selama periode perkembangan fetal. ${ }^{6}$

Sel punca dewasa harus berpotensi klonogenik (clonogenic), artinya harus mampu menghasilkan sekumpulan turunan sel yang identik secara genetik, yang kemudian berkembang menjadi semua sel yang tepat sesuai dengan jaringan di tempat sel tersebut berada., ${ }^{6,7}$ Meskipun masih dapat berdiferensiasi menjadi berbagai jenis sel, diperkirakan sel punca dewasa telah berkurang kemampuan diferensiasinya dan telah menjadi lebih spesifik untuk berdiferensiasi menjadi sel tertentu yang kesemuanya berkontribusi untuk regenerasi jaringan lokal. Sebagai contoh yaitu gastrointestinal crypt cells di sistem pencernaan, oval cells di dalam hati, pneumocytes tipe II di dalam paru-paru, dan berbagai subset sel punca di dalam sum-sum tulang, darah tepi, otak, korda spinalis, pulpa gigi, pembuluh darah, otot rangka, epitel kulit, kornea, retina, dan pankreas. $^{6}$

\section{STROKE}

Penyebab kerusakan otak yang umum terjadi pada orang tua (jarang terjadi pada usia muda) yaitu hilangnya peredaran darah ke otak secara sementara selama terjadinya stroke, sering disebut cedera serebrovaskular. Jenis stroke yang sering ditemukan yaitu stroke iskemia dimana terhambatnya peredaran darah arterial ke/dalam otak akibat adanya penggumpalan darah atau gangguan lain. Jenis stroke yang jarang yaitu stroke hemoragik dimana terjadinya perdarahan disebabkan pecahnya pembuluh arterial di dalam otak. ${ }^{4}$

Tingkatan stroke amat beragam, mulai dari stroke yang hampir tidak terasa hingga yang langsung fatal. Pada kasus stroke iskemia, sel-sel neuron kekurangan pasokan darah, termasuk disini sejumlah besar pasokan oksigen dan glukosa. Pada stroke hemoragik terjadi perdarahan sehingga selsel neuron dibanjiri oleh kelebihan oksigen, kalsium, dan produk lainnya. ${ }^{4}$

Iskemia dan perdarahan dapat menyebabkan berbagai gangguan, di antaranya yaitu edema jaringan otak yang akan meningkatkan tekanan dalam otak dan berpeluang untuk terjadinya stroke lagi. Iskemia dan perdarahan juga mengganggu kerja pompa ion $\mathrm{Na}^{+}, \mathrm{K}^{+}$sehingga terjadi penumpukan ion $\mathrm{Na}^{+}$di dalam sel-sel neuron. Edema dan kelebihan ion $\mathrm{Na}^{+}$akan memicu sel-sel neuron untuk melepaskan neurotransmiter glutamat yang selanjutnya menstimulasi sel-sel neuron secara berlebihan. Ion $\mathrm{Na}^{+}$dan ion-ion lainnya masuk ke dalam sel-sel neuron dalam jumlah berlebihan, melampaui kemampuan pompa ion $\mathrm{Na}^{+}, \mathrm{K}^{+}$untuk mengeluarkan ion-ion tersebut kembali. Ion positif berlebihan akan menghalangi metabolisme dalam mitokondria, yang akhirnya mematikan selsel neuron. Segera setelah terjadi kematian sel-sel neuron, sel-sel glia akan berproliferasi dan menyingkirkan sel-sel neuron yang mati dan debris lainnya. ${ }^{4}$

\section{APLIKASI SEL PUNCA DALAM PENGOBATAN STROKE}

\section{Jenis terapi sel punca: endogen dan eksogen}

Terapi sel punca, antara lain transplantasi sel punca dewasa, merupakan strategi yang menjanjikan dalam penatalaksanaan stroke. Penelitian preklinis menunjukkan aplikasi luas dari sel punca yang berasal dari berbagai jaringan termasuk otak, sumsum tulang, tali pusat, dan jaringan adiposa. Pada gangguan neurologik, tujuan terapi sel punca yaitu menggantikan, memperbaiki, ataupun meningkatkan fungsi biologik dari sel-sel neuron yang rusak untuk memulihkan fungsi otak. Sirkuit neuron fungsional dapat dipulihkan melalui penggantian 
neuron yang rusak. Penelitian terbaru menunjukkan bahwa sel-sel neuron baru dapat dihasilkan dari transplantasi sel punca. Otak dewasa dapat menghasilkan sel-sel neuron baru sebagai respon terhadap kerusakan sel, sehingga memberi harapan bagi pasien stroke. ${ }^{11,13}$

Terapi sel punca pada stroke dapat dikategorikan sebagai jenis endogen dan eksogen. Tujuan terapi sel punca endogen ialah untuk memanfaatkan populasi sel punca dewasa yang secara fisiologik berada di sistem saraf. Pada tipe eksogen, sel punca dewasa atau sel prekursor diberikan melalui injeksi lokal atau sistemik setelah melalui proses pemurnian. Sejumlah kecil sel punca dewasa telah dapat diperoleh dari sum-sum tulang dan darah tali pusat, namun mengenai ekspansinya secara in vitro untuk transplantasi masih memerlukan penelitian lebih lanjut. ${ }^{12,14}$ Terapi sel punca neural eksogen digunakan terutama untuk merekonstruksi sirkuit neuron yang rusak. Sel-sel ini akan memberikan efek neuroprotektif dengan mengeluarkan faktor neurotropik yang mempertahankan perlangsungan hidup sel neuron, baik secara intrinsik atau setelah pemberian transgenik terapeutik. Sel punca multipoten dapat diisolasi dari sistem saraf pusat tikus dewasa dan dikultur in vitro atau pada jaringan otak manusia dewasa. Transplantasi autologus merupakan terapi yang potensial untuk stroke. $^{13,15}$

\section{Jenis-jenis sel punca yang diteliti}

Tujuan utama dari pemeriksaan awal yaitu menilai risiko keselamatan dari identitas sel, metode isolasi, dan prosedur ekspansinya. Setelah didapatkan hasil penilaiannya, maka perbaikan fungsional dari otak menjadi tujuan target dari terapi sel punca. Meskipun beberapa penelitian menunjukkan bahwa beberapa jenis sel yang di injeksikan ke otak setelah stroke dapat mengubah sel donor menjadi sel otak, namun umumnya penelitian sel-sel donor lebih ke arah memberikan perlindungan dan merangsang mekanisme endogen. ${ }^{2,13}$ Saat diinjeksikan pada otak tikus yang iskemik, sel progenitor neural manusia akan bermigrasi ke daerah infark dan mengekspresikan neuroblas dan penanda neuronal imatur, seperti doublecortin dan beta-tubulin. Hal ini juga akan memperbaiki perilaku tikus dan mengecilkan ukuran infark. $^{12,14}$ Pemberian sel punca non-neural juga dapat membantu terapi sel punca neural. Peneliti lainnya juga mengemukakan bahwa transplantasi sel punca pada otak tikus pasca iskemi dapat menginduksi pemulihan fungsional secara bermakna. ${ }^{11}$ Manfaat pemberian sel punca non-neural antara lain memodulasi peradangan; menunjang angiogenesis, neurogenesis, remielinisasi, dan plastisitas aksonal; serta memberikan efek tropik dan efek neuroproteksi. ${ }^{10}$

Sel punca embrionik berpotensi untuk berdiferensiasi dalam tubuh manusia dewasa dan berproliferasi secara in vitro. Secara teoritis, sel punca embrionik dianggap sebagai sel-sel induk yang ideal untuk transplantasi oleh karena bersifat pluripoten. Penelitian yang menggunakan sel punca embrionik yang belum berdiferensiasi mengemukakan bahwa sel-sel tersebut dapat membentuk teratoma ketika ditransplantasikan ke dalam otak. Penggunaan neural progenitor cell (NPC) yang dihasilkan dari sel punca embrionik tikus dapat berdiferensiasi menjadi sel-sel neuron dan glia (termasuk oligodendroglia) secara in vitro. Oleh karena itu, untuk menghindari terjadinya pembentukan teratoma, sel punca embrionik didiferensiasikan dahulu sebelum dilakukan transplantasi. NPC yang diturunkan dari sel punca embrionik ditransplantasikan di otak tikus yang mengalami iskemi setelah reperfusi yaitu ke dalam area iskemik dan menempati sekitar $27 \%$ luas belahan otak iskemik ternyata mengekspresikan saraf penanda dewasa seperti $\beta$-III tubulin empat minggu setelah transplantasi. Selain itu banyak sel punca embrionik dicangkokan berasal dari sel punca neural dapat bertahan dalam inti daerah yang infark sampai 12 minggu. ${ }^{11}$ Liu et al. ${ }^{11}$ melakukan perawatan prahipoksia tikus dengan NPC yang berasal dari sel punca embrionik selama 12 jam 
sebelum transplantasi. Ternyata sel-sel tersebut dapat bertahan hidup dan ketika ditransplantasikan ke otak tikus yang iskemik dapat berdiferensiasi menjadi selsel neuron serta pemulihan neuron sensorik. Salah satu studi yang menggunakan NPC berasal dari kera kemudian sel-sel ini ditransplantasikan ke korpus striatum tikus yang iskemik pada 24 jam setelah reperfusi. Ternyata sel-sel ini bermigrasi ke daerah sekitar lesi iskemik dan berdiferensiasi menjadi berbagai jenis sel neuron dan sel glia. Selanjutnya pada 28 hari pasca transplantasi, sel-sel graft dilabel dengan fluorogold stereotaxically dan disuntikkan ke talamus anterior dan substansia nigra. Bila di bandingkan pada hari ke 14, sel-sel tersebut telah menunjukkan konektivitas ke sel-sel otak residen. ${ }^{16}$

Secara in vitro, sel punca dewasa dapat berproliferasi dengan pemberian berbagai faktor pertumbuhan, yaitu epidermal growth factor (EGF), fibroblast growth factor (FGF), dan faktor penghambat leukemia. Molekul-molekul ini memiliki potensi memperbaiki teknik terapi sel punca. ${ }^{13,14}$ Strategi perbaikan lain yang mungkin dapat dipakai pada pasien stroke yaitu mobilisasi sel progenitor dan sel punca endogen. granulocyte-colony stimulating factor (G-CSF) dapat memicu regenerasi jaringan dan meningkatkan harapan hidup setelah terjadinya stroke dengan cara memobilisasi sel punca sumsum tulang ke darah tepi. Pada pasien didapatkan ukuran infark sangat mengecil dan terdapat pemulihan bermakna dari fungsi neurologik. Hal ini menunjukkan bahwa sel punca dari sum-sum tulang yang termobilisasi dapat berperan pada regenerasi jaringan setelah iskemia serebral lokal. Temuan itu juga menunjukkan bahwa otak yang cedera memiliki kemampuan memperbaiki diri sendiri dan chemokine dapat menarik sel progenitor ke bagian otak yang mengalami infark. ${ }^{11,12}$

Penelitian terbaru menunjukkan efektivitas sel prekursor sum-sum tulang untuk digunakan pada terapi stroke iskemik. Sel punca sum-sum tulang dapat menghasilkan banyak jenis sel dan jaringan, termasuk tulang rawan, jaringan adiposa, otot, hepatosit, glia, dan sel-sel neuron. Penelitian pada hewan coba menunjukkan bahwa injeksi langsung sel punca sum-sum tulang pada penumbra infark saat infark serebral atau mobilisasi sel punca ini setelah infark serebral menghasilkan regenerasi sel-sel neuron dengan peningkatan fungsi otak. Jumlah sel punca sum-sum tulang untuk bertransdiferensiasi menjadi sel-sel neuron sangat kecil, yang mengakibatkan munculnya sel-sel tetraploidi yang terdiri atas sel punca dan sel neuron yang sudah ada sebelumnya. ${ }^{14,17}$ Pada suatu penelitian klinis, sel-sel punca sum-sum tulang autologus diinjeksi secara intravena untuk terapi stroke. Simpulan penelitian tersebut ialah pada pasien dengan infark serebral berat, pemberian infus sel punca autologus tampaknya menjadi pilihan terapi yang terjangkau dan aman yang dapat meningkatkan pemulihan fungsional. ${ }^{12,14}$

Pada penelitian menggunakan hewan coba tikus, sel darah tali pusat manusia dimasukkan melalui vena ekor tikus yang mengalami stroke. Percobaan in vitro ini menunjukkan sel darah tali pusat manusia berdiferensiasi menjadi sel neuron dengan pemberian asam retinoat. Sel-sel ini bermigrasi ke lokasi stroke dan berdiferensiasi menjadi sel neuron dan sel glia. Pemberian melalui vena mungkin merupakan cara yang efektif untuk menangani stroke. Sel darah tali pusat juga meningkatkan kadar faktor tropik di otak yang berkorelasi positif dengan pengecilan ukuran infark dan perbaikan fungsi otak. ${ }^{11,13}$

Transplantasi sel-sel punca untuk stroke memerlukan injeksi banyak jenis sel. Bila infark terjadi di talamus, hipokampus, atau striatum, maka akan melibatkan berbagai populasi sel-sel neuron heterogen. Untuk menentukan jenis lesi stroke yang dapat diperbaiki dengan transplantasi sel punca, banyak penelitian preklinis melakukan injeksi sel-sel punca intrastriatal langsung ke pusat infark, meskipun hasilnya belum jelas. Penelitian lain menunjukkan bahwa daerah penumbra mungkin merupakan lokasi paling tepat untuk menginjeksi sel punca. ${ }^{11,13}$ 


\section{Saat melakukan trasnplantasi sel punca pada stroke}

Mengenai saat yang paling tepat untuk memulai transplantasi sel punca belum terdapat kesepakatan. Cedera iskemik pada stroke merupakan proses progresif dan kematian sel-sel neuron masih dapat terus berlangsung sampai beberapa minggu setelah stroke. Penundaan transplantasi selama berminggu-minggu akan menghadapi risiko terjadinya jaringan ikat, yang akan mempengaruhi keberhasilan terapi sel. Saat terbaik untuk melakukan transplantasi juga tergantung pada kemajuan pemulihan setelah stroke, namun masih sangat sedikit yang diketahui mengenai hasil akhir stroke yang berbeda-beda pada setiap pasien. ${ }^{12,13}$

\section{Masalah etis}

Aplikasi sel punca dalam pengobatan telah memicu perdebatan etis yang dapat mempengaruhi masa depan penelitian selsel tersebut. Banyak hal yang harus disepakati dan diselesaikan sebelum sel-sel punca ini siap untuk menjalani penelitian klinis. Telah dilaporkan bahwa sel punca manusia terkontaminasi patogen dari sel-sel tikus karena menggunakan alat yang sama. Juga tingginya reaksi penolakan jaringan setelah transplantasi dan efek teratogenik perlu dipertimbangkan. Transplantasi secara autologus dari sel punca dewasa memberikan toleransi besar untuk mengatasi penolakan jaringan setelah transplantasi, dan juga dari segi etis. Pada otak manusia yang terkena stroke, peningkatan rekruitment sel punca neural berkontribusi pada neurogenesis akibat stroke. Neuron baru tersebut akan bermigrasi dari zona subventrikular ke striatum yang iskemik. ${ }^{6,12,16}$

\section{Keamanan transplantasi sel punca}

Keselamatan praklinis yang mencakup tumoriginecity, sensitisasi kekebalan tubuh, biodistribusi, dan nasib sel direferensikan dalam Food and Drug Administration (FDA) guidelines. Sel-sel punca yang akan dipakai harus diuji dengan mengikuti langkah-langkah pengecekan untuk men- deteksi potensi pembentukan jaringan tumor, terjadinya kelainan perilaku, dan perubahan fisiologik yang merugikan. ${ }^{16}$

Durasi pengujian keselamatan bervariasi, tergantung pada jenis sel. Sel-sel yang mati dalam beberapa hari sampai minggu setelah injeksi secara in vivo atau yang telah terbukti aman pada pasien dengan gangguan klinis lain mungkin tidak lagi memerlukan pengujian jangka panjang pada hewan coba. Sel-sel yang cepat berproliferasi dan berdiferensiasi membutuhkan pemantauan lebih luas dan jangka panjang secara histopatologik untuk menilai pertumbuhan berlebih dan pembentukan tumor. ${ }^{16}$

Berbagai efek yang tidak diinginkan sangat memerlukan pengamatan yang ketat. Kontrol positif untuk pembentukan tumor atau pertumbuhan berlebih, dan relevansi rejimen imunosupresi harus dipertimbangkan. Semua perilaku buruk selama kehidupan hewan coba setelah injeksi sel harus dievaluasi dan dilacak. Toksisitas akut sistem organ yang relevan harus diuji berdasarkan jalur transplantasi yang digunakan. Sebagai contoh, efek dari sel-sel punca pada aliran darah serebrovaskular atau perfusi serebral harus dievaluasi untuk jalur intra arterial. Fungsi paru harus dievaluasi untuk jalur intravena karena selsel dapat menumpuk di paru-paru yang berperan sebagai saringan pertama. Uji yang dilakukan termasuk fungsi pernapasan dan analisis gas darah arterial. ${ }^{16}$

\section{SIMPULAN}

Stroke masih merupakan masalah kesehatan yang dapat berakibat kecacatan, bahkan sampai fatal. Berbagai jenis pengobatan telah diintroduksi dalam penanganan stroke, tetapi belum memberikan hasil yang memuaskan. Salah satu pengobatan alternatif yang menjanjikan ialah terapi sel punca neural. Pemanfaatan klinis berbagai jenis sel punca masih menghadapi berbagai tantangan baik dari segi teknis maupun etis, terlebih lagi pada penggunaan sel punca embrional. 


\section{DAFTAR PUSTAKA}

1. Wahyu GG. Epidemiologi stroke 17 Juli 2011. [cited 2011 Nov 14]. Available from: http://databaseartikel.com/ kesehatan/20116833-epidemiologistroke.html.

2. HIMAPID FKM UNHAS. Stroke Penyakit Pembunuh Nomor 3 [homepage on the Internet]. 2007 [updated 2007 Dec 24; cited 2011 Nov 14]. Available from: http://himapid.com/2007/12/strokepenyakit-pembunuh-no3.html.

3. Svoboda E. The essential guide to stem cells [homepage on the Internet]. 2009 [updated 2009 Jun 01; cited 2011 Nov 14]. Available from http://www.popsci. $\mathrm{com} / \mathrm{scitech} /$ article/2009-05/essentialguide-stem-cells.

4. Kalat JW. Biopsikologi. Jakarta: Salemba Humanika; 2010.

5. Aini N, Setiawan B, Sandra F. Karakteristik biologis dan diferensisasi stem cell: fokus pada mesenchymal stem cells. Cermin Dunia Kedokteran. 2008;35/161(2):64-67.

6. Tadjudin MK. Aspek bioetika penelitian stem cell. Cermin Dunia Kedokteran. 2006;153:10-11.

7. Halim D, Murti H, Sandra F, Boediono A, Djuwantono T, Setiawan B. Stem Cell Dasar Teori \& Aplikasi Klinis. Jakarta: Penerbit Erlangga; 2010.

8. Setiawan B. Aplikasi terapeutik embryonic stem cell pada berbagai penyakit degeneratif. Cermin Dunia Kedokteran. 2006; $153: 5$.

9. Tiksnadi A, Soertidewi L, Misbach J. Neurorestorasi Sel Punca untuk Stroke. dalam Stroke Aspek, Diagnostik, Patofisiologi, Manajemen. Jakarta: Badan Penerbit FKUI; 2004.

10. Lindvall O, Kokaia $Z$. Stem cell Research in Stroke, How Far From the clinic. Dallas: American Stroke Association; 2011.
11. Liu YP, Lang BT, Baskaya MK, Dempsey RJ, Vemuganti R. The potential of neural stem cells to repair stroke-induced brain damage. Acta Neuropathol. 2009;117(5):469-80.

12. Ding DC, Shyu WC, Lin SZ, Li H. Current concepts in adult stem cell therapy for stroke. Curr Med Chem. 2006;13(29):3565-74.

13. Andres RH, Choi R, Steinberg GK, Guzman R. Potential of adult neural stem cell in stroke therapy. Regen Med. 2008;3(6):893-905.

14. Zhang R, Zhang Z, Wang L, Wang Y, Gousev A, Zhang L, et al. Activated neural stem cells contribute to stroke induced neurogenesis and neuroblast migration toward the infarct boundary in adult rats. J Cereb Blood Flow Metab. 2004;24(4):441-8.

15. Yarygin KN, Kholodenko IV, Konieva AA, Burunova VV, Tairova RT, Gubsky LV, et al. Mechanisms of positive effects of tranplantation of human placental mesenchymal stem cells on recorvery of rats after experimental ischemic stroke. Bull Exp Biol Med. 2009;148(6):862-8.

16. Savitz SI, Chopp M, Deans R, Carmichael ST, Phinney D, Wechsler L. Stem cell Therapy as an Emerging Paradigm for Stroke (STEPS) II. Stroke. 2011;42(3):825-9.

17. Hammer MD, Konziolka D, Wechsler LR. Safety and Efficacy of Transplanting Immortalized Neural Stem cells in Stroke Patients. In: Savitz SI, Rosenbaum DM, editors. Stroke Recovery with Cellular Therapies. Totowa, New Jersey: Humana press, 2008; p.1-9.

18. Mescher AL. Junqueira's Basic Histology Text \& Atlas (Twelfth Edition). Singapore: The McGraw-Hill Companies Inc; 2010. 